\title{
Molecular fragments chemoinformatics
}

\author{
Hubert Kuhn ${ }^{1^{*}}$, Stefan Neumann ${ }^{2}$, Christoph Steinbeck $^{3}$, Carsten Wittekindt ${ }^{*}$, Achim Zielesny ${ }^{4}$ \\ From 5th German Conference on Cheminformatics: 23. CIC-Workshop \\ Goslar, Germany. 8-10 November 2009
}

The description of chemical structures as a collection of connected molecular fragments is a basic requirement of coarse grained simulation methods like molecular fragment dynamics. These methods use molecular fragments as their basic interacting entities ("atoms") and allow the modelling and investigation of very large chemical systems. Therefore a molecular fragments chemoinformatics is in need that supports the fragmentbased representation of chemical structures as well as the elementary operations upon them. The poster outlines definitions and approaches to tackle these issues from an adequate molecular line notation up to the graphical representation of simulation boxes.

\footnotetext{
Author details

${ }^{1}$ CAM-D, Essen, Germany. ${ }^{2}$ GNWI, Oer-Erkenschwick, Germany. ${ }^{3}$ European Bioinformatics Institute (EBI), Hinxton, UK. ${ }^{4}$ University of Applied Sciences of Gelsenkirchen, Institute for Bioinformatics and Chemoinformatics,

Recklinghausen, Germany.
}

Published: 4 May 2010

\section{Publish with ChemistryCentral and every} scientist can read your work free of charge

"Open access provides opportunities to our colleagues in other parts of the globe, by allowing anyone to view the content free of charge." W. Jeffery Hurst, The Hershey Company.

- available free of charge to the entire scientific community

- peer reviewed and published immediately upon acceptance

- cited in PubMed and archived on PubMed Central

- yours - you keep the copyright

Submit your manuscript here:

http://www.chemistrycentral.com/manuscript/<smiles>c1ccccc1</smiles>
Chemistry Central 